\title{
Ideological Narration in Chudori's Pulang and Laut Bercerita: A Žižek Perspective in Literary Analysis
}

\author{
Gaguk Adi Masdianto ${ }^{1}$, Setya Yuwana Sudikan ${ }^{2,}$ Darni $^{3}$ \\ 1. Postgraduate Student of Indonesian Language and Literature Education, Universitas Negeri Surabaya, Indonesia \\ (State University of Surabaya) \\ 2 and 3 , Advisors
}

\begin{abstract}
Problem of ideology in Žižek's perspective is on the practice of subject. Subject can be out of ideological manipulation which has radical action to ruin the ideological domination. It is what Chudori narrates in Pulang (Going Home) and Laut Bercerita (Sea Tells). Those novels narrate a radical movement against the ideological state that dominates them. To reach the result, hermeneutic technique of analysis is used. It results that Pulang and Laut Bercerita narrate a movement to ruin the totalitarian government. It is relevant to the historical facts of how the totalitarian government in Indonesia was ruined. By adding some hidden facts that are untold in general narration, this analysis explains ideological narration of struggle against the totalitarian control in Chudori's perspective.
\end{abstract}

Key Words: Narration, Ideology, Subject, Žižek

DOI: $10.7176 /$ JLLL/54-08

Publication date:March $31^{\text {st }} 2019$

\section{Introduction}

The historical narration is represented by Leila S. Chudori in her fiction Pulang (2012) and Laut Bercerita (2017). Pulang can be regarded as a historical genre of fiction with various dramas and themes such as family, friendship, love and betrayal. Of course, this novel draws on the background of three historical events, starting from the September 30, 1965 Movement in Indonesia, the May 1968 Event in France, and the May 1998 Reformation in Indonesia.

Pulang tells the story of Dimas Suryo, an Indonesian political exile, who settled in Paris, France. Before getting asylum in France, he and several journalists and artists, were expelled and could not return to Jakarta because their passports had been revoked by the Indonesian government. The lack of legality of the passport made them wasted in France, before that, they had gone to Santiago, Havana, Peking, until finally getting asylum and settling in France.

Dimas founded the Tanah Air Restaurant in Paris with three fellow comrades, Nug, Tjai, and Risjaf. They call themselves the Four Pillars of the Motherland. In the midst of running restaurants and the raging of Paris at that time, Dimas received news from Jakarta that Hananto Prawiro, his best friend who was still in Indonesia, was captured by the army and killed. Of course, he was constantly pursued with guilt because his friends in Indonesia were killed one by one or at least disappeared in the hunt for the 30 September events. On the other hand, Dimas Suryo, who was also involved in student demonstrations in Paris, met Vivienne Deveraux, a French student who also participated in the demonstration. From the meeting, Dimas finally married Vivienne and was blessed with a daughter, Lintang Utara.

In May 1998, when Lintang had grown up as a student, he wished to carry out a historical study of the victims of the September 30, 1965 tragedy. He wanted to investigate how the history of bleeding in his father's country of origin, and how his father and his friends struggled in the tragedy. When he arrived in Indonesia, he met Segara Alam, the son of Hananto Prawiro. Lintang and Segara witnessed historical event in Indonesia, the May 1998 riots. It was also a moment of the fall of the Indonesian President, Suharto, who had authoritarian rule for 32 years.

If it is seen at a glance, from the plot, the novel tries to gather historical events and bridge two major events between the events of September 30, 1965 (Indonesia) - May 1968 (Paris) with reformation in May 1998 (Indonesia). The existence of figures explains implicitly another perspective from these political events through a more humanist perspective, or it can be said, is very full of memory. The problem, the involvement of Dimas as an political exile strongly explains that he is part of the strength of resistance to a political power. Although Dimas is a neutral journalist, as reviewed by Soefandi in IDNTimes, 
When his co-workers were busy arguing about the most correct ideology, Dimas was more likely to be accommodative. Dimas's attitude is shown while maintaining his friendship with those who tend to be 'left' - Nugroho and Hananto - and Mas Amir who tend to be 'right' idols (Soefandi, 2017-author's translation).

But the loss of Dimas explained that he could not neutralize his political position, "even though Dimas tends to be neutral, and does not want to be compartmentalized by ideology, almost all of the time is spent with all three left-leaning themes" (Soefandi, 2017) and this can be a reference to trace the root of the problem until it becomes exile. The attitude of nationalism plunged into the abyss of chaos, as a left-wing political man but married to a French girl. There are nuances of emotional grudge towards Hananto, who marries Surti (Dimas's ex-boyfriend) while sleeping with Marni. The left political exile context in Dimas is very psychological, and indeed, ideology will not be separated from its construction in the subconscious of the subject. In other words, he is in ideological uncertainty. Therefore, the real situation to talk is the ideological narration in these novel as a discovery of historical facts.

\section{Research Method}

The type of this research is qualitative. The used approach is mimetic. The data are the quotations in the novel related to the problem. The sources of data are Chudori's Pulang and Laut Bercerita. The technique of data collection is documentation. The steps to collect the data are reading, taking quotations, and classifying the data. The technique of analysis is hermeneutic (heuristic technique and hermeneutic technique). The steps to analyze are initiating the problem, data display, interpreting with inter-textualizing with historical facts and theoretical perspective, and concluding.

\section{Result and Discussion}

For the record, the September 30 movement (G30S) itself was an attempt to overthrow illegal and overt coup d'état by a military, apparatus or other elite and the movement killed at least six Indonesian Army generals in its efforts to stage a coup, but in the end, the coup attempt failed (see Crouch, 1978: 101; Powell \& Thyne, 2011).

After the failed coup attempt, the situation became even tenser because soldiers, socio-political groups, and many religious leaders alleged that the coup attempt was commandeered by the Indonesian Communist Party (PKI). From there, mass cleansing took place, which resulted in the imprisonment and death of suspected, suspected and claimed sympathizers of Communism. Under the command of the New Order regime, the G30S were given additional PKI attributes by those who wanted to associate them with the PKI (see Roosa, 2006: 29).

Apart from investigating many versions of the bloody event, in fact the incident has created a series of facts that many people were killed (apart from their symbolic status as an ideologue, army, political figure, etc.) and many missing people and the luckiest were those who were exiled. Exile is a way to protect themselves before becoming a victim of the incident and here Dimas explains how he got lost in the country as an exile politician, even though he finally married a girl from a country he borrowed, had a child who would bring memories of his exile back home Indonesia, but with relevant conflicts, a coup. If Dimas became a witness indirectly from the G30S/PKI which was a failed coup against the government, then Lintang became a clear witness of the 1998 Reformation which was a successful coup against the government. The problem is, does history and the events that occur politically teach the figures that this is only about political power struggles where the people, or subjects, are only used as a tool in playing the throne? If Dimas, as Budiawan said on the official website of Leila S. Chudori, is a true nationalist, "Dimas Suryo, political exile who is the central figure in this novel, is told as someone who always harbored hopes and desires to return to Indonesia, whether alive or die" (Budiawan, 2013), then what prompted him to stay in France and marry a French girl? In ideological studies, this condition is a true parallax (double views) (between loving his people or securing himself in another country) from how the subject actually does not do what is known (that is wrong if he lives in France); an ideological fantasy.

Similar but not the same, parallel stories with historical conflicts are also elaborated in Laut Bercerita. If Pulang begins a historical event with memories of events in 1965-1968, Laut Bercerita begins the story in March 1998, or the moment before reform took place, in Jakarta. It is said that one evening, in a flat in Jakarta, a student named Biru Laut, and some of his friends, such as Daniel Tumbuan, Sunu Dyantoro, Alex Perazon, were arrested by four mysterious men. They are carried and hidden in a mysterious place. They were tortured and interrogated about the figure behind the student activist movement at that time. The kidnapping of activists 
certainly caused concern for most people, especially for the families of the victims. From that problem, the younger brother of Biru Laut, Asmara Jati, in 2000, along with the Missing Persons Commission Team led by Aswin Pradana, tried to find traces of the lost activist parra, starting from seeking information from Anjani, Blue Sea lover, parents and wives of the lost activist. Briefly, the main problem of this novel is a real exploration from the point of view of Biru Laut as a victim of the kidnapping and disappearance of several activists who participated in the overthrow of the Soeharto regime.

President Soeharto's government was threatened by the overthrow of activists in the fact that there were many activists who went down, this was implicitly explained that it was the practice of Soeharto's power by maximizing the functions of state apparatus to destroy everything that could trigger or threaten his power. The question is almost the same as what has been offered before, if the activists from among these students staged a coup, for what reason did they do it? This question finally answered itself when a revolutionary attitude only became a reformist attitude. This means that the ideological order in political power only changed patterns and left the remnants of the previous power. Maybe, the face is new, but the system of government is still the same; they will be led by several people who have contributed to their overthrow. That way, people as political subjects are not really present, and they are actually used as political tools, or in Slavoj Žižek's terms, ideological fantasies that offer ideological objects as a driving force for people to desire them.

In Melanie Budianta's view, this novel places the position of Leila S. Chudori as a humanitarian activist with a political agenda to" resist forgetting historical moments related to state violence (Budianta, 2018). If we understand the context of the revolution, take the example of the French revolution, and then we will realize that the turmoil and hatred of the proletariat against the French bourgeoisie was accommodated through the destruction of the Bastille prison which created social trauma. The term trauma is very close to the subconscious. Trauma will not be forgotten, so Budianta's concern in seeing Chudori as a fictional figure as an act of forgetting is precisely explaining that it is only reform, not a revolution, and that reform does not seem to create trauma, because after reformation, similar cases in reformation are still happened, "the historical debt of 1998, as in the case of Munir's murder, violence against journalists, until the 1965 tragedy continued to demand public participation not to stop talking" (Budianta, 2018).

In political science, a revolution (derived from Latin, revolutio, which in English translates to a turn around, which if translated in Indonesian becomes a reversal) is a spontaneous fundamental change in a political power from a rebellious attitude towards society or the people against government, usually because of oppression (political, social, economic) (see Bullock \& Trombley, 1999: 754-746). If indeed Indonesia evolved, then there would be a total reversal or change of a system, as in France, which changed from a constitutional monarchy to a republic, and what happened in Indonesia? Of course, as a critical responsive attitude to what Budianta said, it can be said that criticism is easier to express because it is free in mind, but reality still goes on. The writers can explore poverty, cruelty, and the abyss of injustice, but behind it, the writer gets what he does not realize he wants; legitimacy. Again, this becomes a paradox between what is known about what is done; an ideological fantasy.

A simple sentence like this, in Pulang, Dimas, who experienced exile as a political exile, was eager to return to Indonesia and save his friends, but in fact he argued about passports and so on and instead married a French girl, had children there, and left his nationalist feeling was through his son who was about to go home. It strongly implies that discourse is very easy in the context of ideology, because ideology is not just naive awareness (the subject does not know, but the subject does it), but also cynical awareness (the subject knows, but the subject still does it) (Žižek, 1989: 24), so the problem is the action of Dimas. This is no longer about memories, sympathetic feelings, or insignificant turmoil. The struggle is not about the mind, but it is about attitude, real action, and true revolution.

Meanwhile, Laut Bercerita also implies a failure of the revolution. This novel can be said to be a very melancholy novel for victims, but it is not a lost victim that is at the root of the problems of the Indonesian state, but the coup process turned out to be only a transition from a political power to another political power. This means that there is a very organized ideological force that regulates the scheme of activists' desire to activate their actions to overthrow the existing government and perpetuate the power of the group. Therefore, this movement or coup is better known as Reformation than a Revolution (new birth) (see Setiawan, 2015: 163-164).

These two novels imply the main problems that have occurred in Indonesia, not from sympathizers or cries of the victims in every historic event in Indonesia, but rather how Indonesia is a fertile land for the power of the political elite concerned. That is a picture of how radical actions from every event that happened, actually 
twisted into an ideological fantasy. If it can be said, Indonesia is the manifestation of various political negotiation spaces where power is the logical consequences of its political practice.

Classical Marxists regard ideology as a false consciousness. False consciousness refers to an illusion that deceives the subject, so that whatever seen by the subject is actually an illusion that has been planned to be made like that. The subject cannot see reality. Marx briefly summarizes it into a phrase, "sie wissen das nicht, aber sie tun es (they do not know it, but they are doing it)" (žižek, 1989: 24). False awareness causes the subject not to reach the reality. There is a kind of thick illusion that obscures the reality behind it. From this situation, everything that people believe is a lie or illusion created by a certain particular group. With this blindness, people will only do what they do not know.

Žižek views that ideology works in a cynical state. There is a kind of subconscious force that encourages them to continue to do, as mentioned by Sohn-Rethel, that there is an impulse as if or as if (als ob) which regulates the scheme of the existence of a promising fetish object and captivates the subject so that he faithfully submit and obey the ideological illusion (see Žižek, 1989: 11-12).

Žižek sees that compliance is a logical consequence of the subject's psychological state. As a Lacanian, he believed that the subject was stranded in the subconscious mind which trapped him in symbolic conditions. It is well known in general, Lacan divides the psychological development of the subject into three orders, the imaginary, the symbolic, and the real.

In the beginning of a person is a real world, where all needs are met without any shortcomings. But the separation between self and this need creates a break in one's ego and that lack is characterized by the process of identifying the ego, which is also called the imaginary order (mirror stage). The self is still an individual who tends to be ego-centric, which has not been able to identify and distinguish between himself and the other.

The other is an image that is not himself (it can be said as the presence of an image from another person that creates a distance between himself and the non-self and this becomes a process of self-identification). The sense of neediness becomes increasingly immanent and permanent in one's subconscious when the ego is subdued by the symbolic order. The symbolic order is the order that rapes the ego in a linguistic manner. Language offers meaning, meaning creates culture, and culture constructs society. The problem is meaning, for Lacan, it does not exist, it is the Other (O capital). Its absence is due to the structure of language that has no markers, only a chain of endless markers.

Paradoxically, the absence of the Other actually pumps the subject's desire to fulfill it, even though it doesn't exist. If the subject knows if he is not there, then the subject will not desire, and if the subject is not desirous, then there will be no more life force. Therefore, in this Symbolic order, the ego is absent and it is castrated by language to become the subject (sub which means below, second, minor, and iacio which means subjugated). The subject is a person who is subdued by his exteriority.

The process of fulfilling that desire also guarantees jouissance which makes the subject become so complacent as if it is getting fulfillment. Of course, there was a person who delivered the subject to get the object of the Other's success, and Lacan called it fantasy. Fantasy is not a post-condition, it is a pre-condition of all desires. Desire can be turned on as far as fantasy creates a scheme that can be followed by desire and drive (drive) from fantasy is the principle of pleasure

If it is withdrawn in a socio-political context, what makes society subject to power is because the power has immersed a phantasmatic ideological scheme so that every subject who experiences reality immediately falsifies it into a meaningful and deceptive great values and manipulation. With the practice going on, ideological fantasies are already underway. When a society that has power is subject to weakness towards a handful of people in the government, it explains the meaning of this fantastic ideological work. Therefore, if it is drawn further into the context of the class struggle à la Marxist, Žižek precisely strips it off by implying that the class struggle is also an ideological practice, if it is ideological practice, then it does not do a pure act, but carries out a new practice of power. This is what is represented in the historical strokes and events that took place in Indonesia, whose sadness is also implied in Pulang and Laut Bercerita by Leila S. Chudori; two novels that recount major events in Indonesian history. In general, historical events bound by the two novels tend to show that there is a kind of action which is categorized as radical to overthrow the power of government. Of course, these events represent the actual actions of a group of subjects; momentum. 


\section{Conclusion}

What underpins the assumptions in this article is that the bloody history of Indonesia represented in a memorial and sympathetic way by Leila S. Chudori in the novel Pulang and Laut Bercerita, is a picture of how radical actions are the momentum of any shift in power in Indonesia. This is the ideological narration in Chudori's novel.

\section{Acknowledgement}

I would like to express my deep gratitude to Rector of State University of Surabaya, the Director of Postgraduate Program, and the advisors, Prof Dr Setya Yuwana Sudikan, MA and Dr. Darni; thank you for your dedication, guidance, assistance, and integrity, without being tired to guide me to learn and keep on studying. Thank you very much.

\section{Bibliography}

Budianta, Melani. 2018. Laut Bercerita: Antara Mengingat dan Melupakan Sebuah Pembacaan. [online]. Diakses dari http://www.leilaschudori.com/id/indonesia-laut-bercerita-antara-mengingat-dan-melupakansebuah-pembacaan.

Budiawan. 2013. Tentang novel "Pulang” karya Leila S. Chudori dan Kontekstualisasi Fakta Historisnya. [online]. Diakses dari https://www.leilaschudori.com/tentang-novel-pulang-karya-leila-s-chudori-dankontekstualisasi-fakta-historisnya.

Bullock, Allan \& Trombley, Stephen. 1999. The New Fontana Dictionary of Modern Thought (Edisi ke-3). New York: HarperCollins.

Chudori, Leila S, 2012. Novel Pulang Cetakan Kesembilan 2017. Jakarta: PT. Gramedia.

Chudori, Leila S, 2017. Novel Laut Bercerita. Jakarta: PT. Gramedia.

Crouch, Harold. 1978. The Army and Politics in Indonesia, Politics and International Relations of Southeast Asia. Ithaca: Cornell University Press.

McGlynn, John H., dkk. 2007. Indonesia in the Soeharto Years: Issues, Incidents and Images (Edisi ke-2). Jakarta: The Lontar Foundation.

Powell, Jonathan M. \& Thyne, Clayton L. 2011. "Global instances of coups from 1950 to 2010 A new dataset". Journal of Peace Research. 48 (2): 249-259. doi:10.1177/0022343310397436. ISSN 0022-3433.

Roosa, John. 2006. Pretext for Mass Murder: The September 30 ${ }^{\text {th }}$ Movement and Suharto's Coup d'État in Indonesia. Madison: The University of Wisconsin Press.

Setiawan, Rahmat, 2015. Fantasi Ideologis dalam Novel The White Tiger Karya Aravind Adiga: Perjumpaan Subjek-Subjek Sastra Melalui Perspektif Slavoj Žižek. Yogyakarta: Universitas Gadjah Mada.

Soefandi, Achmad. 2017. Ulasan Novel Pulang Karya Lela S. Chudori: Kisah Tentang Mereka yang Terpinggirkan. IDN Times [online]. Diakses dari https://www.idntimes.com/fiction/story/achmadsoefandi/review-buku-ulasan-novel-pulang-karya-lela-s-chudori-kisah-tentang-mereka-yangterpinggirkan-c1c2/full.

Žižek, Slavoj. 1989. The Sublime Object of Ideology. London \& New York: Verso. 